\title{
Pengaruh Marketing Mix Terhadap Keputusan Nasabah Menabung dengan Religiusitas sebagai Variabel Moderasi
}

\author{
Cyntia Novita Sari', Fernaldi Anggadha Ratno2, \\ Email: cyntianovita09@gmail.com¹, anggadharatno@iainsalatiga.ac.id², \\ 1,2Institut Agama Islam Negeri Salatiga, \\ 1,2Jl. Tentara Pelajar No. 2, Salatiga, Jawa Tengah.
}

\begin{abstract}
This study aims to measure and analyze the effect of the marketing mix (product, place, price, promotion, process, people and physical evidence) on customer decisions to save at BRI Syariah KC Semarang and the influence of religiosity in moderating the effect of marketing mix on customer decisions to save in BRI Syariah KC Semarang. Based on the results of the study it can be concluded that the first marketing mix (product, place, price, promotion, process, people and physical evidence) has a significant positive effect on customer decisions to save, secondly religiosity moderates the effect of marketing mix on customer decisions to save and third there is a significant positive effect. simultaneous between the marketing mix and the customer's decision to save.
\end{abstract}

Keywords: product, place, price, promotion, process, people, physical evidence, customer decision to save, religiosity.

\begin{abstract}
Abstrak
Penelitian ini bertujuan untuk mengukur dan menganalisa pengaruh marketing mix (produk, tempat, harga, promosi, proses, orang dan bukti fisik) berpengaruh terhadap keputusan nasabah menabung di BRI Syariah KC Semarang serta pengaruh religiusitas dalam dalam memoderasi pengaruh marketing mix terhadap keputusan nasabah menabung di BRI Syariah KC Semarang. Berdasarkan hasil penelitian dapat disimpulkan bahwa pertama marketing mix (produk, tempat, harga, promosi, proses, orang dan bukti fisik) berpengaruh positif signifikan terhadap keputusan nasabah menabung, kedua religiusitas memoderasi pengaruh marketing mix terhadap keputusan nasabah menabung dan ketiga terdapat pengaruh yang positif signifikan simultan antara marketing mix terhadap keputusan nasabah menabung.
\end{abstract}

Kata Kunci: produk, tempat, harga, promosi, proses, orang, bukti fisik, keputusan nasabah menabung, religiusitas.

\section{Pendahuluan}

BRI Syariah resmi beroperasi pada 17 November 2008 dengan nama PT Bank BRI Syariah. Hal tersebut berdasarkan adanya bukti akuisisi yang dilakukan oleh PT Bank Rakyat Indonesia (Persero) terhadap Bank Jasa Arta pada tanggal 19 Desember 2007 serta mendapatkan izin usaha dari Bank Indonesia melalui No. 10/67/Kep.GBI/DPG/2008 pada 16 Oktober 2008. 


\section{Pengaruh Marketing Mix Terhadap Keputusan Nasabah Menabung dengan Religiusitas sebagai Variabel Moderasi}

Cyntia Novita Sari, Fernaldi Anggadha Ratno

Seluuh kegiatan usaha BRI Syariah bersadarkan prinsip syariah Islam. Sebagai bank ritel modern yang memiliki kapabilitas tinggi, BRI Syariah fokus membidik berbagai segmen masyarakat. Hal tersebut dapat dilihat dari berbagai basis nasabah yang terbentuk secara luas diseluruh penjuru Indonesia. Pada tanggal 9 Mei 2018, BRI Syariah mengambil langkah lebih pasti dengan melaksanakan Initial Public Offering di Bursa Efek Indonesia. IPO ini menjadikan BRI Syariah sebagai anak usaha BUMN dibidang syariah yang pertama melaksanakan penawaran umum saham perdana (www.brisyariah.co.id).

Pada tahun 2014 nasabah berjumlah 20.550, tahun 2015 nasabah berjumlah 23.798, tahun 2016 nasabah berjumlah 27.96o, tahun 2017 nasabah berjumlah 34.948, tahun 2018 nasabah berjumlah 43.053 dan pada tahun 2019 nasabah berjumlah 50.800. Meskipun jumlah nasabah setiap tahunnya mengalami peningkatan, namun pertumbuhan jumlah nasabah tidak stabil padahal marekting mix yang dilakukan oleh BRI Syariah KC Semarang untuk menarik nasabah sangat gencar dilakukan pada tahun 2019 yaitu dengan melakukan kerjasama dengan universitas-univesritas dan juga sekolah-sekolah dan ikut serta menjadi sponsor dalam kegiatan yang ada di Semarang maupun daerah-daerah lain.

\section{Tinjauan Teoritik}

Menurut Eisenfuhr dalam Lunenburg (2010) pengambilan keputusan merupakan proses membuat keputusan mengenai pilihan dari sejumlah alternatif yang ada guna untuk mencapai hasil yang diinginkan. Dari defisi di atas terdapat tiga kunci elemen. Yang pertama, pengambilan keputusan dimana didalamnya melibatkan mengenai membuat pilihan dari sejumlah pilihan. Kedua, pengambilan keputusan yaitu sebuah proses yang didalamnya melibatkan lebih dari sekedar pilihan akhir sebagai alternatif pilihan yang ada. Dan yang ketiga, "hasil yang diinginkan" yang telah disebutkan sebelumnya dalam definisi yang melibatkan tujuan atau target yang dihasilkan diperoleh melalui aktivitas mental yang berasal dari si pembuat keputusan yang mana ia terlibat dalam mencapai keputusan akhir. 
Menurut Kotler (2016:4026) menjelaskan pengambilan keputusan pembelian terdiri dari lima tahap yaitu:

1. Menganalisis keinginan dan kebutuhan

2. Pencarian informasi dan penelian sumber-sumber pembelian

3. Seleksti terhadap alternatif pembelian

4. Keputusan untuk membeli

5. Perilaku sesudah membeli.

Produk adalah pemahaman produsen atau sesuatu baik yang berwujud fisik maupun tidak, yang bisa ditawarkan oleh perusahaan sebagai usaha untuk mencapai tujuaan organisasi melalui pemenuhan kebutuhan dan keinginan konsumen. Keputusan pembelian merupakan keputusan konsumen untuk membeli suatu produk dimana sebelum konsumen telah memikirkan tentang layak atau tidaknya produk tersebut dengan mempertimbangkan informasiinformasi yang ia ketahui (Setiadi, 2013). Hal ini didukung oleh penelitian dari Rusdianto (2016), Djunaedi (2016) dan Asraf (2014) yang menyatakan bahwa produk berpengaruh signifikan terhadap minat menabung.

Dalam sebuah usaha bagi perusahaan lokasi merupakan suatu tempat dimana perusahaan dapat menyediakan jasanya. Bentuk-bentuk pelayanan yang berkaitan dengan transaksi di bank syariah juga berkaitan dengan bagaimana lokasi bank itu sendiri (Markus, 2015:19-20). Keputusan pembelian merupakan keputusan konsumen untuk membeli suatu produk dimana sebeluna konsumen telah memikirkan tentang layak atau tidaknya produk tersebut dengan mempertimbangkan informasi-informasi yang ia ketahui (Setiadi, 2013). Hal ini didukung oleh penelitian Wundi (2014) yang menyatakan bahwa tempat berpengaruh positif signifikan.

Menurut Swastha (2012) harga merupakan sejumlah uang (ditambah beberapa barang) yang dibutuhkan untuk mendapatkan sejumlah kombinasi barang serta mendapatkan pelayanan. Keputusan pembelian merupakan keputusan konsumen untuk membeli suatu produk dimana sebelumnya konsumen telah memikirkan tentang layak atau tidaknya produk tersebut dengan memeprtimbangkan informasi-informasi yang ia ketahui (Setiadi, 2013). Hal ini didukung oleh penelitian Eka Wundi Lilis Kustiningsih (2014), 


\section{Pengaruh Marketing Mix Terhadap Keputusan Nasabah Menabung dengan Religiusitas sebagai Variabel Moderasi}

Cyntia Novita Sari, Fernaldi Anggadha Ratno

Puryono (2014) yang menyatakan bahwa harga secara simultan berpengaruh signifikan terhadap keputusan menjadi nasabah tabungan faedah.

Menurut Staton dalam Sunyono (2014:58) promosi adalah unsur yang terdapat dalam bauran pemasaran yang digunakan untuk memberitahu, membujuk dan mengingatkan tentang produk perusahaan. Keputusan pembelian merupakan keputusan konsumen untuk membeli suatu produk dimana sebelumnya konsumen telah memikirkan tentang layak atau tidaknya produk tersebut dengan mempertimbangkan informasi-informasi yang ia ketahui (Setiadi, 2013). Hal ini didukung dengan penelitian Sarwita (2017) dan Nurlaeli (2017) menatakan bahwa promosi signifikan mempengaruhi keputusan pembelian.

Proses adalah gabungan dari semua aktivitas yang terdiri dari prosedur, jadwal, pekerjaan, mekanisme dan hal-hal rutin dimana jasa yang dihasilkan nantinya akan disampaikan kepada konsumen (Markus, 2015:19-20). Keputusan pembelian merupakan keputusan konsumen untuk membeli suatu produk dimana sebelumnya konsumen telah memikirkan tentang layak atau tidaknya produk tersebut dengan mempertimbangkan informasi-informasi yang ia ketahui (Setiadi, 2013). Hal ini didukung oleh penelitian Detha Alfrian Fajri, dkk (2013) dan Sumantri (2014) menyatakan bahwa proses simultan mempunyai pengaruh yang signifikan terhadap proses keputusan menabung.

Orang merupakan semua pelaku yang memainkan peran dalam penyajian jasa. Indikator dalam penelitian ini yaitu prosedur partisipasi tim layanan dan eksekusi layanan, sistem dan prosedur imbal jasa untuk mobilitas kerja, pelatihan skill interaksi dan resolusi masalah nasabah. Keputusan pembelian merupakan keputusan konsumen untuk membeli suatu produk dimana sebelumnya konsumen telah memikirkan tentang layak atau tidaknya produk tersebut dengan memeprtimbangkan informasi-informasi yang ia ketahui (Setiadi, 2013). Hal ini didukung oleh penelitian Wilson Setiawan (2014) Yulianto (2011) dan Alfrian (2013) menyatakan bahwa orang secara simultan mempunyai pengaruh yang signifikan terhadap keputusan menabung.

Kondisi fisik merupakan lingkungan fisik perusahaan tempat jasa diciptakan dan tepat penyediaan jasa untuk konsumen berinteraksi ditambah 
unsur tangibel apa saja yang digunakan dalam mengkomunikasikan atau mendukung peranan dalam jasa (Markus, 2015:19-20). Keputusan pembelian merupakan keputusan konsumen untuk membeli suatu produk dimana sebelumnya konsumen telah memikirkan tentang layak atau tidaknya produk tersebut dengan mempertimbangkan informasi-informasi yang ia ketahui (Setiadi, 2013). Hal ini didukung oleh penelitian Wundi (2014) dan Pour, Nazari dan Emmani (2013) menyatakan bahwa wujud fisik berpengaruh signifikan terhadap keputusan keputusan menjadi nasabah tabungan faedah.

Religiusitas merupakan suatu keadaan yang terdapat dalam diri seseorang yang mendorong untuk berfikir, bersikap, berperilaku dan bertindak sesuai dengan ajaran agama (Maisur, dkk, 2015). Produk adalah pemahaman produsen atau sesuatu baik yang berwujud fisik maupun tidak, yang bisa ditawarkan oleh perusahaan sebagai usaha untuk mencapai tujuaan organisasi melalui pemenuhan kebutuhan dan keinginan konsumen.

Menurut penelitian yang dilakukan oleh Azzahra (2016) menyatakan bahwa religiusitas sebagai variabel moderasi ini memiliki pengaruh yang positif signifikan terhadap pengaruh keputusan nasabah menabung dengan referensi pengetahuan mengenai bank syariah. Religiusitas merupakan suatu keadaan yang terdapat dalam diri seseorang yang mendorong untuk berfikir, bersikap, berperilaku dan bertindak sesuai dengan ajaran agama (Maisur, dkk, 2015). Lokasi yang strategis dapat menentukan pencapaian tujuan badan usaha. Menurut Kotler (2008) salah satu kunci keberhasilan suatu badan usaha yaitu penentuan lokasi yang strategis. Apabila terdapat suatu badan usaha yang berdiri dengan posisi lokasi yang mudah dijangkau maka hal tersebut akan mempermudah masyarakat untuk menjangkaunya dan menggunakan produknya. Penelitian ini didukung dengan penilitian yang dilakukan oleh Purnawati (2016) dimana hasilnya menunjukkan bahwa lokasi dimoderasi terhadap keputusan pembelian.

Religiusitas merupakan suatu keadaan yang terdapat dalam diri seseorang yang mendorong untuk berfikir, bersikap, berperilaku dan bertindak sesuai dengan ajaran agama (Maisur, dkk, 2015). Menurut Swastha (2012) harga merupakan sejumlah uang (ditambah beberapa barang) yang dibutuhkan untuk mendapatkan sejumlah kombinasi barang serta mendapatkan pelayanan. Dari 


\section{Pengaruh Marketing Mix Terhadap Keputusan Nasabah Menabung dengan Religiusitas sebagai Variabel Moderasi}

Cyntia Novita Sari, Fernaldi Anggadha Ratno

penelitian yang dilakukan oleh Muanas, A dan Suhermin (2014) ini menyimpulkan bahwa harga berpengaruh signifikan terhadap keputusan pembelian.

Religiusitas merupakan suatu keadaan yang terdapat dalam diri seseorang yang mendorong untuk berfikir, bersikap, berperilaku dan bertindak sesuai dengan ajaran agama (Maisur, dkk, 2015). Menurut Staton dalam Sunyono (2014:58) promosi adalah unsur yang terdapat dalam bauran pemasaran yang digunakan untuk memberitahu, membujuk dan mengingatkan tentang produk perusahaan. Penelitian yang dilakukan oleh Fatmawati (2015) ia menyatakan bahwa dari hasil penelitian tersebut religiusitas berpengaruh positif signifikan terhadap informasi mengenai produk-produk tabungan.

Religiusitas merupakan suatu keadaan yang terdapat dalam diri seseorang yang mendorong untuk berfikir, bersikap, berperilaku dan bertindak sesuai dengan ajaran agama (Maisur, dkk, 2015). Proses adalah gabungan dari semua aktivitas yang terdiri dari prosedur, jadwal, pekerjaan, mekanisme dan hal-hal rutin dimana jasa yang dihasilkan nantinya akan disampaikan kepada konsumen (Markus, 2015:19-20).

Penelitian yang dilakukan oleh Rahman dan Haque (2015) diperoleh hasil bahwa niat beli konsumen merupakan bias persepsi konsumen yang bisa muncul karena dorongan emosional dan fanatisme agama. Penelitian yang dilakukan oleh Lestari (2015) menyatakan bahwa terdapat pengaruh yang signifikan antara religiusitas terhadap preferensi mahasiswa untuk menabung di bank syariah. Religiusitas merupakan suatu keadaan yang terdapat dalam diri seseorang yang mendorong untuk berfikir, bersikap, berperilaku dan bertindak sesuai dengan ajaran agama (Maisur, dkk, 2015). Orang merupakan semua pelaku yang memainkan peran dalam penyajian jasa. Indikator dalam penelitian ini yaitu prosedur partisipasi tim layanan dan eksekusi layanan, sistem dan prosedur imbal jasa untuk mobilitas kerja, pelatihan skill interaksi dan resolusi masalah nasabah. Penelitian yang dilakukan oleh Shandi (2015) menyatakan bahwa orang berpengaruh positif signifikan terhadap keputusan pembelian. 
Religiusitas merupakan suatu keadaan yang terdapat dalam diri seseorang yang mendorong untuk berfikir, bersikap, berperilaku dan bertindak sesuai dengan ajaran agama (Maisur, dkk, 2015). Kondisi fisik merupakan lingkungan fisik perusahaan tempat jasa diciptkan dan tepat penyediaan jasa untuk konsumen berinteraksi ditambah unsur tangibel apa saja yang digunakan dalam mengkomunikasikan atau mendukung peranan dalam jasa (Markus, 2015:19-20). Penelitian yang dilakukan oleh Puryono (2014) menyatakan bahwa bukti fisik berpengaruh positif signifikan terhadap keputusan pembelian

Marketing mix adalah bauran pemasaran dimana dalam strateginya dengan mencampurkan kegiatan-kegiatan pemasaran, dengan tujuan yaitu untuk menemukan kombinasi maksimal yang bertujuan dapat mendatangkan hasil yang maksimal (Alma, 2014:143). Dari penelitian yang dilakukan oleh Febriana (2016) ia menyatakan bahwa marketing mix berpengaruh positif signifikan simultan terhadap keputusan nasabah menabung.

\section{Metode Penelitian}

Penelitian ini merupakan jenis penelitian kuantitatif yaitu penelitian yang dimana datanya diperoleh langsung dari sumbernya atau langsung dari objek penelitian melalui penyebaran kuesioner dengan melibatkan seluruh populasi. Sumber data yang digunakan dalam penelitian ini adalah data primer yaitu data yang diperoleh langsung dari sumbernya atau langsung dari objek penelitian. Data ini diperoleh dengan cara melakukan penelitian langsung dengan pengamatan observasi dan juga penyebaran kuesioner.

Populasi adalah keseluruhan objek yang diteliti yang ciri-cirinya akan diduga (estimated) oleh peneliti. Ciri-ciri populasi disebut parameter, karenanya populasi sering diartikan sebagai kumpulan objek penelitian dari mana data akan dikumpulkan untuk dianalisis (Noor, 2015:41). Populasi yang digunakan penulis diambil dari nasabah Bank BRI Syariah KC Semarang dengan jumlah 200.109 orang (Sumber data nasabah BRI Syariah KC Semarang).

Sampel adalah sebagian atau wakil dari populasi yang diteliti (Arikunto, 2010). Sampel didefinisikan sebagai objek atau subjek yang dipilih guna mewakili keseluruhan penelitian Menurut Bawono (2006). Adapun sampel yang 


\section{Pengaruh Marketing Mix Terhadap Keputusan Nasabah Menabung dengan Religiusitas sebagai Variabel Moderasi}

Cyntia Novita Sari, Fernaldi Anggadha Ratno

digunakan penulis dalam penelitian ini yaitu dengan menggunakan teknik sampling purposive. Sampling purposive adalah teknik penentuan sampel dengan pertimbangan tertentu (Sugiyono, 2015:85). Maka jumlah sampel yang digunakan oleh peneliti yaitu sejumlah 100 responden.

Variabel yang digunakan dalam penelitian ini adalah:

1. Variabel bebas (variabel independen)

variabel bebas dalam penelitian ini adalah marketing mix (produk (X1), tempat (X2), harga $\left(\mathrm{X}_{3}\right)$, promosi $\left(\mathrm{X}_{4}\right)$, proses $\left(\mathrm{X}_{5}\right)$, harga (X6) dan bukti fisik $\left.\left(\mathrm{X}_{7}\right)\right)$.

2. Variabel terikat (variabel dependen)

Variabel terikat dalam penelitian ini adalah keputusan nasabah menabung (Y).

3. Variabel moderasi

Variabel moderasi dalam penelitian ini adalah religiusitas (Z).

\section{Hasil Dan Pembahasan}

Diketahui uji ANOVA atau F didapat nilai F hitung sebesar 18.804 dengan probabilitas 0,000, karena probabilitas < 0,05, maka model regresi ini dapat digunakan untuk memprediksikan Keputusan Nasabah untuk Menabung atau dapat dikatakan bahwa Product, Place, Price, Promotion, Process, People, Physical Evidance, Religiusitas secara bersama-sama berpengaruh terhadap Keputusan Nasabah untuk Menabung di Perbankan Syariah.

Diketahui dari tabel uji t terdapat persamaan regresi sebagai berikut:

$$
\begin{aligned}
& \mathrm{Y}=\alpha+\beta 1 X 1+\beta 2 X 2+\beta 3 X 3+\beta 4 X 4+\beta 5 X 5+\beta 6 X 6+\beta 7 Z+e \\
& \mathrm{Y}=5,906+0,028 \mathrm{X} 1+0,111 \mathrm{X} 2+0,146 \mathrm{X}_{3}+0,136 \mathrm{X} 4+0,040 \mathrm{X} 5+0,365 \mathrm{X} 6 \\
& +\mathrm{o}, 009 \mathrm{Z}+\mathrm{e}
\end{aligned}
$$

Dari model persamaan regresi di atas dapat diambil kesimpulan bahwa:

1) Konstanta sebesar 5,906 meyatakan jika variabel indpeden dianggap konstan, maka rata-rata keputusan nasabah akan naik sebesar 5,906 satuan.

2) Koefisien produk (X1) sebesar 0,208 dengan nilai signifikansi sebesar 0,003 $<$ o,05 menyatakan bahwa setiap kenaikan atau penurunan satu satuan produk mempengaruhi keputusan nasabah menabung. 
3) Koefisien tempat (X2) sebesar 0,111 dengan nilai signifikansi sebesar 0,012 < 0,05 menyatakan bahwa setiap kenaikan atau penurunan satu satuan tempat mempengaruhi keputusan nasabah menabung.

4) Koefisien harga ( $\mathrm{X}_{3}$ ) sebesar 0,146 dengan nilai signifikansi sebesar 0,034< 0,05 menyatakan bahwa setiap kenaikan atau penurunan satu satuan harga mempengaruhi keputusan nasabah menabung.

5) Koeifisien promosi (X4) sebesar 0,136 dengan nilai signifikansi sebesar 0,048 < 0,05 menyatakan bahwa setiap kenaikan atau penurunan satu satuan promosi mempengaruhi keputusan nasabah menabung.

6) Koefisien proses $\left(X_{5}\right)$ sebesar 0,040 dengan nilai signifikansi sebesar 0,004 $<$ o,05 menyatakan bahwa setiap kenaikan atau penurunan satu satuan proses mempengaruhi keputusan nasabah menabung.

7) Koefisien orang (X6) sebesar 0,228 dengan nilai signifikansi sebesa 0,025 < 0,05 meyatakan bahwa setiap kenaikan atau penurunan satu satuan orang mempengaruhi keputusan nasabah menabung.

8) Koefisien bukti fisik $\left(X_{7}\right)$ sebesar 0,009 dengan nilai signifikansi sebesar 0,010 < 0,05 menyatakan bahwa setiap kenaikan atau penurunan nilai satu satuan bukti fisik mempengaruhi keputusan nasabah menabung.

9) Koefisien religiusitas (Z) sebesar o,536 dengan nilai signifikansi sebesar 0,000 < 0,05 meyatakan bahwa setiap kenaikan atau penurunan nilai satu satuan religiusitas mempengaruhi keputusan nasabah menabung. apabila nilai signifikan < 0,05 atau 5\% maka masing-masing variabel dinyatakan signifikan.

Sementara itu, tingkat signifikansi dapat diketahui dari nilai masingmasing variabel tersebut adalah:

1) Produk (X1) memiliki koefisien 0,028 , nilai $t$ sebesar 0,396 dan nilai signifikansi o,003, artinya variabel produk berpengaruh positif signifikan terhadap keputusan nasabah menabung.

2) Tempat (X2) memiliki nilai koefisien o,111, nilai t sebesar 1,443 dan nilai signifikansi sebesar 0,012 < 0,05, artinya tempat berpengaruh positif signifkan terhadap keputusan nasabah menabung. 


\section{Pengaruh Marketing Mix Terhadap Keputusan Nasabah Menabung dengan Religiusitas sebagai Variabel Moderasi}

Cyntia Novita Sari, Fernaldi Anggadha Ratno

3) Harga $\left(\mathrm{X}_{3}\right)$ memiliki nilai koefisien 0,146 nilai t sebesar 1,511 dan nilai signifikansi 0,034 < 0,05, artinya harga berpengaruh positif signifikan terhadap keputusan nasabah menabung.

4) Promosi (X4) memiliki nilai signifikansi 0,136, nilai t sebesar 2,006 dan nilai signifikansi $0,048<0,05$, artinya promosi berpengaruh positif signifikan terhadap keputusan nasabah menabung.

5) Proses (X5) memiliki nilai koefisien sebesar 0,040 nilai t 0,520 sebesar dan nilai signifikansi $0,004<0,05$ artinya proses berpengaruh positif signifikan terhadap keputusan nasabah menabung.

6) Orang (X6) memiliki nilai koefisien sebesar 0,228 , nilai t sebesar 2,280 dan nilai signifikansi sebesar 0,025 < 0,05, artinya orang berpengaruh positif signifikan terhadap keputusan nasabah menabung.

7) Bukti fisik memiliki nilai koefisien sebesar 0,009, nilai t sebesar 0,125 dan nilai signifikansi $0,010>0,05$, artinya bukti fisik berpengaruh positif signifikan terhadap keputusan nasabah menabung.

8) Religiusitas memiliki nilai koefisien sebesar 0,536 nilai t sebesar 8,769 dan nilai signifikansi sebesar $0,000<0,05$, artinya religiusitas berpengaruh positif signifikan terhadap keputusan nasabah menabung.

Berdasarkan hasil penelitian dapat diketahui bahwa besarnya adjusted $\mathrm{R}^{2}$ adalah 0,590. Hal ini berarti variasi variabel independen dapat menjelaskan variasi variabel dependen sebesar 59,0\%. Sedangkan sisanya $(100 \%-59,0 \%=$ 41,0\%) yakni 41,0\% dijelaskan oleh variasi variabel lain diluar model penelitian.

Hasil dari uji MRA diketahui bahwa variabel produk berpengaruh positif signifikan terhadap keputusan nasabah menabung di BRI Sariah KC Semarang. Dengan kata lain bahwa produk berpengaruh terhadap keputusan nasabah menabung. Hal inn sejalan dengan penelitian yang dilakukan oleh Asraf (2014) yang menyatakan bahwa produk berpengaruh positif signifikan terhadap keputusan menyimpan dana. Dengan demikian hal ini menunjukkan produk yang dimiliki oleh BRI Syariah mampu meningkatkan keputusan nasabah untuk menabung, karena mereka percaya dan yakin dengan menggunakan produk bank syariah mereka dapat merasa aman dan tentram. 
Hasil dari uji MRA diketahui bahwa variabel produk berpengaruh positif signifikan terhadap keputusan nasabah menabung di BRI Sariah KC Semarang. Hal ini sejalan dengan penelitian Rizqa (2012) yang menyatakan bahwa lokasi memiliki pengaruh positif signifikan terhadap keputusan nasabah menabung. Lokasi yang strategis dapat menentukan pencapaian tujuan badan usaha. Menurut Kotler (2008) salah satu kunci keberhasilan suatu badan usaha yaitu penentuan lokasi yang strategis. Apabila terdapat suatu badan usaha yang berdiri dengan posisi lokasi yang mudah dijangkau maka hal tersebut akan mempermudah masyarakat untuk menjangkaunya dan menggunakan produknya.

Hasil dari uji MRA diketahui bahwa variabel produk berpengaruh positif signifikan terhadap keputusan nasabah menabung di BRI Sariah KC Semarang, Hal ini sejalan dengan penelitian yang dilakukan Ivany Rachmawati (2017) yang menyatakan bahwa harga berpengaruh positif signifikan terhadap keputusan nasabah. Hal ini menunjukkan bahwa harga dalam menggunakan produk bank sejalan dengan keinginan mereka, seperti biaya administrasi yang ringan, harga sesuai dengan kualitas, porsi bagi hasil yang sesuai dan lain sebagainya, sehingga hal tersebut menyebabkan berpengaruh positif signifikan.

Hasil dari uji MRA diketahui bahwa variabel produk berpengaruh positif signifikan terhadap keputusan nasabah menabung di BRI Sariah KC Semarang, Hal ini sejalan dengan penelitian yang dilakukan oleh Sarwita (2017) yang menyatakan bahwa promosi berpengaruh positif signifikan terhadap keputusan untuk menabung. Kegiatan promosi dalam suatu usaha menjadi salah satu hal yang penting untuk mempromosikan produknya. Dengan adanya kegiatan tersebut membuat konsumen tertarik akan produk tersebut dan ingin menggunakannya.

Hasil dari uji MRA diketahui bahwa variabel produk berpengaruh positif signifikan terhadap keputusan nasabah menabung di BRI Sariah KC Semarang . Hal ini sejalan dengan penelitian yang dilakukan oleh Yulianto (2010) yang menyatakan bahwa proses memiliki pengaruh dan signifikan terhadap pertimbangan nasabah dalam memilih bank. Hal ini menunjukkan bahwa ketika nasabah melakukan transaksi di BRI Syariah KC Semarang, nasabah 


\section{Pengaruh Marketing Mix Terhadap Keputusan Nasabah Menabung dengan Religiusitas sebagai Variabel Moderasi}

Cyntia Novita Sari, Fernaldi Anggadha Ratno

merasa puas, oleh sebab itu nasabah menganggap terlalu penting proses dalam pengambilan keputusan untuk menabung.

Hasil dari uji MRA diketahui bahwa variabel produk berpengaruh positif signifikan terhadap keputusan nasabah menabung di BRI Sariah KC Semarang . Hal ini sejalan dengan penelitian yang dilakukan Alfrian (2013) yang menyatakan bahwa orang memiliki pengaruh positif yang signifikan terhadap proses seseorang untuk menabung. Hal ini menunjukkan bahwa responden merasa puas dengan kinerja para karyawan bank syariah serta pengetahuan karyawan mengenai produk-produk sudah kompeten

Dari hasil Uji MRA diketahui bahwa bukti fisik berpengaruh positif signifikan terhadap keputusan nasabah menabung di BRI Syariah KC Semarang. Hal ini sejalan dengan penelitian yang dilakukan Alfrian (2013) yang menyatakan bahwa orang memiliki pengaruh positif yang signifikan terhadap proses seseorang untuk menabung.. Hal ini menunjukkan bahwa nasabah menganggap penting bukti fisik dalam pengambilan keputusan untuk menabung di bank.

Untuk variabel produk, promosi dan orang merupakan variabel yang paling berpengaruh terhadap keputusan nasabah menabung. Hal tersebut dibuktikan dengan adanya penghargaan yang diperoleh oleh BRI Syariah KC Semarang yaitu penghargaan yang diterima dari majalah info bank, penghargaan Peringkat II Tabungan Bank Umumm Syariah dan Best Overall Peringkat III Tabungan Bank Umum Syariah, The Best Bank In Digital Services dan The Most Efficient Bank \& The Most Reliable Bank.

\section{Kesimpulan}

Berdasarkan penelitian yang dilakukan maka dapat diambil kesimpulan bahwa terdapat pengaruh yang signifikan dari variabel produk terhadap keputusan nasabah menabung di BRI Syariah KC Semarang. Hal ini berdasaran dari hasil uji MRA dimana produk memiliki koefisien 4,011 nilai t sebesar 4,058 dan nilai signifikansi $0,000<0,05$. Sehingga produk (X1) berpengaruh positif signifikan terhadap keputusan nasabah menabung di BRI Syariah KC Semarang. Terdapat pengaruh yang signifikan dari variabel tempat terhadap 
keputusan nasabah menabung di BRI Syariah KC Semarang. Hal ini berdasaran dari hasil uji MRA dimana tempat memiliki sebesar 2,664 dengan nilai $t$ sebesar 2,411 signifikansi sebesar 0,18 < 0,05 menyatakan bahwa tempat (X2) berpengaruh terhadap keputusan nasabah menabung. Terdapat pengaruh yang signifikan dari variabel harga terhadap keputusan nasabah menabung di BRI Syariah KC Semarang. Hal ini berdasarkan dari hasil uji MRA dimana harga memiliki nilai koefisien 0,228 nilai t sebesar 2,280 dan nilai signifikansi 0,28 < 0,05, artinya harga $\left(\mathrm{X}_{3}\right)$ berpengaruh positif signifikan terhadap keputusan nasabah menabung. Terdapat pengaruh yang signifikan dari variabel promosi terhadap keputusan nasabah menabung di BRI Syariah KC Semarang. Hal ini berdasarkan dari hasil uji MRA dimana promosi memiliki nilai signifikansi 0,329 , nilai t sebesar 3,680 dan nilai signifikansi $0,000<0,05$, artinya promosi (X4) berpengaruh positif signifikan terhadap keputusan nasabah menabung. Terdapat pengaruh yang signifikan dari variabel proses terhadap keputusan nasabah menabung di BRI Syariah KC Semarang. Hal ini berdasarkan dari hasil uji MRA dimana proses memiliki nilai koefisien sebesar 0,218 nilai t 2,044 dan nilai signifikansi $0,044<0,05$ artinya proses $\left(\mathrm{X}_{5}\right)$ berpengaruh positif signifikan terhadap keputusan nasabah menabung. Terdapat pengaruh yang signifikan dari variabel orang terhadap keputusan nasabah menabung di BRI Syariah KC Semarang. Hal ini berdasarkan dari hasil uji MRA orang memiliki nilai koefisien sebesar 4,840 nilai t sebesar 1,047 dan nilai signifikansi sebesar o,o0o $<0,05$, artinya orang (X6) berpengaruh positif dan signifikan terhadap keputusan nasabah menabung. Terdapat pengaruh yang signifikan dari variabel bukti fisik terhadap keputusan nasabah menabung di BRI Syariah KC Semarang. Hal ini berdasarkan dari hasil uji MRA bukti fisik memiliki nilai koefisien sebesar 0,219, nilai t sebesar 2,049 dan nilai signifikansi 0,043 < 0,05, artinya bukti fisik $\left(\mathrm{X}_{7}\right)$ berpengaruh positif signifikan terhadap keputusan nasabah menabung. Hasil Uji Moderated Regession Analysis menunjukkan nilai signifikansi sebesar 0,005 lebih kecil dari 0,05 dengan hasil unstandardized coefficients $\mathrm{B}$ positif artinya religiusitas dalam memoderasi berpengaruh positif signifikan terhadap keputusan nasabah menabung. Hasil Uji Moderated Regession Analysis menunjukkan nilai signifikansi sebesar 0,005 lebih kecil dari 0,05 dengan hasil unstandardized coefficients B positif 


\section{Pengaruh Marketing Mix Terhadap Keputusan Nasabah Menabung dengan Religiusitas sebagai Variabel Moderasi}

Cyntia Novita Sari, Fernaldi Anggadha Ratno

artinya religiusitas dalam memoderasi berpengaruh positif signifikan terhadap keputusan nasabah menabung. Hasil Uji Moderated Regession Analysis menunjukkan hasil nilai signifikansi sebesar 0,017 lebih kecil dari 0,05 dengan nilai unstandardized coefficients $\mathrm{B}$ positif artinya religiusitas dalam memoderasi berpengaruh positif signifikan terhadap keputusan nasabah menabung. Hasil Uji Moderated Regession Analysisi menunjukkan hasil nilai signifikansi sebesar 0,045 lebih kecil dari 0,05 dengan nilai unstandardized coefficients B positif artinya religiusitas dalam memoderasi berpengaruh positif signifikan terhadap keputusan nasabah menabung. Hasil Uji Moderated Regession Analysisi menunjukkan hasil nilai signifikansi sebesar 0,023 lebih besar dari 0,05 dengan nilai unstandardized coefficients B positif artinya religiusitas dalam memoderasi berpengaruh positif signifikan terhadap keputusan nasabah menabung. Hasil Uji Moderated Regession Analysisi menunjukkan hasil nilai signifikansi sebesar 0,000 lebih kecil dari 0,05 dengan nilai unstandardized coefficients $\mathrm{B}$ negatif artinya religiusitas dalam memoderasi berpengaruh positif signifikan terhadap keputusan nasabah menabung. Hasil Uji Moderated Regession Analysisi menunjukkan hasil nilai signifikansi sebesar 0,018 lebih kecil dari 0,05 dengan nilai unstandardized coefficients B positif artinya religiusitas dalam memoderasi berpengaruh positif signifikan terhadap keputusan nasabah menabung. Dari Uji ANOVA atau F didapat nilai hitung sebesar 18,804 dengan probabilitas o,ooo karena probabilitas jauh lebih kecil dari 0,05 maka model regresi dapat digunakan untuk memprediksi Keputusan Nasabah untuk Menabung atau dapat dikatakan bahwa Produk, Tempat, Harga, Promosi, Proses, Orang, Bukti fisik dan Religiusitas secara bersama-sama berpengaruh terhadap Keputusan Nasabah untuk Menabung di Perbankan Syariah.

\section{Daftar Pustaka}

Alfrian, Detha. Desember 2013. "Pengaruh Bauran Pemasaran Jasa Terhadap Keputusan Menabung (Survei Pada Nasabah Bank Muamalat Cabang Malang)”. Jurnal Admnistrasi Bisnis (JAB). Vol.6 (2). 
Asraf. Januari 2014. "Pengaruh Kualitas Terhadap Keputusan Menyimpan Dana Bank Muamalat Indonesia Cabang Pasaman Barat Dengan Religiusitas Sebagai Variabel Moderator". Jurnal Apresiasi Ekonomi. Vol.2: 61-72.

Azzahra. 2016. "Pengaruh Pengetahuan dan Disposbale Income Terhadap Preferensi Menabung di Bank Syariah Dengan Religiusitas sebagai Variabel Moderasi (Studi Mahasiswa Fakultas Ekonomi dan Bisnis Islam UIN Sunan Kalijaga).

Djunaedi. 2016. "Pengaruh Coorporate Social Responsibility (CSR) dan Kualitas Produk Terhadap Citra Bank dan Keputusan Menabung di Bank BNI Syariah Kota Kediri”. Jurnal Ilmu Ekonomi \& Manajemen, 3(2): 104-119.

Eka, Wundi Lilis Kustiningsih . 2014. "Variabel-Variabel yang Mempengaruhi Keputusan Menjadi Nasabah Tabungan Faedah BRI Syariah di Samarinda”. e-Jourrnal Ilmu Administrasi Bisnis. 2014 Vol 2 (2): 201-214.

Fajar. 2015. "Pengaruh Promosi, Lokasi, dan Kualiatas Pelayanan Terhadap Keputusan Nasabah Menabung pada Bank Mandiri”.

Fatmawati, Desi. 2015. "Pengaruh Pendapatan, Religiuistas, dan Informasi Terhadap Intensitas Menabung di Bank Syariah pada Kalangan Santri Mahasiswa PP. Wahid Hashim di Sleman. Skripsi: Universitas Negeri Yogyakarta.

Haque A, Rahman S dan Haque M. 2011. "Religiuosity, Ethnocentrism and Corporate Image Toward The Perception of Young Muslim Consumers: Structural Equation Modelling Approach”. European Journal of Social Scienties, 23 (1) 98-108

Kotler, P. 2012. Manajemen Pemasaran. Jilid 3. Jakarta: Bumi Angkasa. .

Lunenburg, Fred C. 2010. "Communication: The Process, Barries, And Improving Effectiveness". Schooling, Vol. 1, No.1.

Maisur, Muhammad Arfan, M. Shabri. 2015. Pengaruh Prinsip Bagi Hasil Tingkat Pendapatan, Reigiusitas Dan Kualitas Pelayanan Terhadap Keputusan Menabung Nasabah Pada Bank Syariah Di Banda Aceh. Jurnal Magister Akuntansi, 4 (2): 1-18.

Nurleli. 2017. "Pengaruh Faktor Budaya, Psikologi, Pelayanan, Promosi dan Pengetahuan Tentang Produk Terhadap Keputusan Nasabah Memilih BPRS di Banyumas”. Jurnal Pemikiran Islam, 18(2): 75-106. 
Pengaruh Marketing Mix Terhadap Keputusan Nasabah Menabung dengan Religiusitas sebagai Variabel Moderasi

Cyntia Novita Sari, Fernaldi Anggadha Ratno

Pour, Nazari dan Emmani. 2013. "The Effect of Marketing Mix in Attracting Customers: case Study of Saderat Bank in Kermanshah Province". African Journal of Business Management, $7(34): 3272-3280$.

Puryono. 2014. "Pengaruh Marketing Mix. Terhadap Keputusan Pembelian pada UD Gladah Wangi di Magetan.” Jurnal Ilmu\&Riset Manajemen Vol. No. 11 (2014).

Sarwita. 2017. "Pengaruh Kualitas Pelayanan dan Promosi Terhadap Keputusan Nasabah Untuk Menabung (Studi Kasus Pada Perumda BPR Majalengka)". Jurnal Ilmiah Manajemenen\&Akuntansi, 4(1): 3645 .

Setiadi. 2013. Perilaku Konsumen (edisi revisi). Yogyakarta: Graha Ilmu.

Wundi, Eka. 2014. "Variabel-Variabel Yang Mempengaruhi Keputusan Menjadi Nasabah Tabungan Faedah Bank BRI Syariah Cabang Samarinda”. eJournal Ilmu Administrasi Bisnis. Vol. 2 (2): 201214.

Yulianto, Firman. Oktober 2010. "Analisis Pengaruh Faktor Bauran Pemasaran Terhadap Pertibambangan Nasabah Dalam Memilih Bank Syariah di Kota Medan. Jurnal Ekonomi Vol.13 (4).

www.brisyariah.co.id 